Uniwersytet w Białymstoku

Wydział Filologiczny

Instytut Filologii Wschodniosłowiańskiej

tel. +48857457450

e-mail: michal1437@gmail.com

\title{
Imiona chrzestne bielskich prawosławnych i katolików na przełomie XIX i XX wieku
}

Słowa kluczowe: językoznawstwo, onomastyka, antroponimia, imiona

\section{Wstęp}

Czynnik wyznaniowy, jak wiadomo, odgrywa istotną rolę w badaniach antroponimicznych. Jego uwzględnienie niezbędne jest przede wszystkim w odniesieniu do obszarów etnicznie mieszanych. Do takich miejsc należy miasto Bielsk Podlaski, które od samego początku swojego istnienia wyróżniało się wielonarodowością i wielokonfesyjnością. Założone w XI wieku przez księcia Jarosława Mądrego jako średniowieczny gród ulokowany na styku wpływów wschodnio- i zachodniosłowiańskich, a także na pograniczu słowiańsko-bałtyckim, kilkakrotnie zmieniało swą przynależność państwową. Po włączeniu do Wielkiego Księstwa Litewskiego (w XIV w.) Bielsk zyskał na znaczeniu politycznym, społecznym i gospodarczym. W 1495 roku otrzymał z rąk Aleksandra Jagiellończyka prawa miejskie magdeburskie. Na przełom XVI i XVII wieku przypada największy rozwój miasta, który związany był z rozkwitem rzemiosła. U schyłku XVIII wieku Bielsk trafił pod panowanie pruskie (1796-1807), po czym został wcielony do Cesarstwa Rosyjskiego ${ }^{1}$.

1 Więcej na temat historii miasta zob. m.in. Mazuruk, Fionik 2003; Sosna, Fionik 1995; Kosieradzki 1987. 
Uwzględniony w niniejszym opracowaniu przedział czasowy (18901909) charakteryzował się ożywieniem gospodarczym miasta, spowodowanym w znacznej mierze uruchomieniem linii kolejowej łączącej Kijów, Brześć, Bielsk i Białystok [Mazuruk, Fionik 2003, 17]. Liczba bielszczan na przełomie XIX i XX w. oscylowała w różnych latach w granicach od ok. 6900 do ok. 7800 osób. W 1884 roku, na przykład, w mieście mieszkało 7101 osób (prawosławni - 3248, rzymscy katolicy - 1821, Żydzi - 2019, muzułmanie - 13) [Соркіна 2011, 57]. Cztery lata później Bielsk zamieszkiwało ok. 7000 osób, w 1897 r. - ok. 8400 [Sosna, Fionik 1995, 41-42], zaś w 1900 r. - 7815 [Mazuruk, Fionik 2003, 17]. Według spisu z 1914 r., w przededniu I wojny światowej w mieście było 7443 obywateli, a struktura wyznaniowa kształtowała się w sposób następujący: prawosławni - 2682 osoby, katolicy - 2137, protestanci - 13, Żydzi - 2608, muzułmanie - 3 [Семянчук 2013, 36, 41-42].

Przedmiotem niniejszego artykułu są imiona chrzestne bielszczan dwóch obrządków - prawosławnego i rzymskokatolickiego. Materiał źródłowy wynotowano z ksiąg metrykalnych ${ }^{2}$ czterech bielskich parafii prawosławnych (św. Trójcy, Narodzenia NMP, św. Michała Archanioła i Zmartwychwstania Pańskiego) oraz jedynej $\mathrm{w}$ tym czasie parafii katolickiej pw. Narodzenia NMP i św. Mikołaja ${ }^{3}$.

W okresie zaboru rosyjskiego w Bielsku były rozmieszczone liczne oddziały wojskowe. W II połowie XIX w. w mieście stacjonowały m.in.: Pułk Izmajłowski Lejb Gwardii, Sofijski Pułk Piechoty, pół eskadronu Petersburskiego Pułku Ułańskiego, część 5. Dońskiego Pułku Kozackiego, 102. Pułk Wiatski oraz 62. Suzdalski Pułk Piechoty. Na początku XX wieku stacjonował I Kadrowy Batalion Obozowy [Fionik 2015, 59-67]. Z zachowanych spisów można wywnioskować, że najliczniejszą grupą narodowościową wśród żołnierzy byli Rosjanie, ale służbę wojskową pełnili także Białorusini, Polacy i inni. Oprócz wojskowych, w Bielsku na przełomie XIX i XX w. zamieszkiwała też pewna liczba Rosjan piastujących lokalne stanowiska urzędnicze, m.in. Naczelnika Bielskiej Izby Skarbowej, Pisarza Zarządu Wojskowego, Naczelnika Sądu Okręgowego ${ }^{4}$ lub pełniących służbę w innych miejscach kluczowych dla funkcjonowania miasta. Część mundurowych i urzędników po zakończeniu swojej służby wraz ze swoimi najbliższymi opuszczała

\footnotetext{
2 Księgi parafialne z interesującego nas okresu (1890-1909) znajdują się w Archiwum Państwowym w Białymstoku (zespoły 940/0, 941/0, 1047/0, 1049/0, 1420/0).

3 Wszystkie te parafie obejmowały nie tylko obszar Bielska, ale także okoliczne wsie (w przypadku kościoła katolickiego było ich ponad 20). Bielszczanie w każdym przypadku stanowili zdecydowanie mniejszy odsetek wszystkich wiernych należących do danej parafii.

4 Więcej na ten temat zob. m.in. Fionik 2011, 25-28.
} 
Bielsk, inni pozostawali w mieście na stałe. Nie znając losów konkretnej rodziny trudno jest jednoznacznie uznać jej członków za rdzennych bielszczan. Przyjęto zatem, że odrębne zestawienia frekwencyjne zostaną poświęcone rodowitym mieszkańcom miasta, osobno zaś będzie mowa o ochrzczonych dzieciach urodzonych w rodzinach urzędników i wojskowych. Sytuacja tego typu dotyczy wiernych Kościoła prawosławnego, jak również, w nieco mniejszym stopniu, Kościoła rzymskokatolickiego ${ }^{5}$.

\section{Imiona chrzestne bielszczan wyznania prawosławnego}

W latach 1891-1909 w bielskich parafiach prawosławnych ochrzczono łącznie 804 osoby (429 chłopców i 375 dziewczynek) urodzone w rodzinach szlacheckich i mieszczańskich zamieszkujących na terenie miasta. Charakterystyczną cechą imiennictwa tego obrządku jest jednoimienność, dlatego suma nadań imion równa jest liczbie ochrzczonych dzieci. W nominacji męskiej wykorzystano 55 niepowtarzających się imion, w nominacji żeńskiej - 41 .

\subsection{Imiona prawosławne męskie}

\section{a) popularność imion}

W nazewnictwie męskim najpopularniejszymi imionami były: Иван Иоанн (41), Александр (40), Владимир (35), Иосиф (34), Павел (28), Михаил (27), Николай (24). Mniejszym zainteresowaniem cieszyły się: Петр (20), Константин (18), Антоний (14), Сергий/Сергей (14), Василий (11), Григорий (11), Алексий/Алексей (10). Do grupy imion używanych rzadko należy zakwalifikować: Георгий (9), Димитрий (8), Емилиан (8), Феодор (7), Борис (6), Андрей (5), Евгений (4), Леонид (4), Симеон (4), Афанасий (3), Евфимий (3), Иаков/Яков (3), Игнатий (3), Иоаким (3), Иулиан (3), Виктор (2), Вячеслав (2), Лев (2) oraz 23 ітіоna, które w badanym okresie wystąpiły tylko jeden raz: Авксентий, Аркадий, Арсений, Дионисий, Евстафий, Иероним, Климент, Лаврентий, Леонтий, Мартин, Матфей, Митрофан, Моисей, Никифор, Онуфрий, Серафим, Сильвестр, Стефан, Тимофей, Тихон, Трофим, Феофан, Фома.

5 Na przykład, według rejestru szeregowych Pułku Suzdalskiego, stacjonującego w Bielsku podczas spisu ludności w 1897 roku, figurujących tam żołnierzy można podzielić na 4 grupy wyznaniowe: 73 prawosławnych, 12 katolików, 7 Żydów i 3 muzułmanów [zob. Семянчук 2015, 75-83].

6 Wszystkie przykłady cytowane są w uproszczonej ortografii. Pominięto zatem znak ъ występujący w wygłosie imion męskich oraz ujednolicono zapis liter $u, \oint$ i in. 
b) udział imion ze stanowiska motywacji religijno-kulturowej

\begin{tabular}{|c|c|c|}
\hline Źródła imion & Liczba imion & Liczba użyć imion \\
\hline Imiona biblijne ST & $6(10,9 \%)$ & $70(16,3 \%)$ \\
\hline Imiona biblijne NT & $9(16,4 \%)$ & $99(23,1 \%)$ \\
\hline Imiona biblijne związane poprzez tradycję & $1(1,8 \%)$ & $3(0,7 \%)$ \\
\hline Imiona świętych starochrześcijańskich (do V w.) & $36(65,4 \%)$ & $214(49,9 \%)$ \\
\hline Imiona świętych średniowiecza & $3(5,4 \%)$ & $43(10,0 \%)$ \\
\hline Razem & $55(100 \%)$ & $429(100 \%)$ \\
\hline
\end{tabular}

Udział poszczególnych grup imion uwzględniający ich motywację religijno-kulturową ${ }^{7}$ można analizować pod różnym kątem. Możliwe jest ustalenie zarówno frekwencji jednakowych (niepowtarzających się) imion, jak też stwierdzenie ilościowego (i procentowego) uczestnictwa imion w zakresie łącznej liczby ich użycia.

Powyższe dane wskazują, że niezależnie od przyjętej rachuby najczęściej korzystano z imion motywowanych postaciami świętych starochrześcijańskich. W mniejszym stopniu posłużono się imionami biblijnymi nowotestamentowymi i starotestamentowymi oraz imionami nawiązującymi do świętych średniowiecza.

c) udział imion ze względu na pochodzenie językowe

W prawosławnym imiennictwie męskim zagadnienie to kształtuje się w sposób następujący:

\begin{tabular}{|c|c|c|}
\hline Pochodzenie językowe imion & Liczba imion & Liczba użyć imion \\
\hline semickie (hebrajskie, aramejskie) & $9(16,4 \%)$ & $115(26,8 \%)$ \\
\hline egipskie & $1 \quad(1,8 \%)$ & $1 \quad(0,2 \%)$ \\
\hline greckie & $32(58,2 \%)$ & $187(43,6 \%)$ \\
\hline łacińskie & $10(18,2 \%)$ & $83(19,3 \%)$ \\
\hline słowiańskie & $3(5,4 \%)$ & $43(10,0 \%)$ \\
\hline Razem & $55(100 \%)$ & $429(100 \%)$ \\
\hline
\end{tabular}

7 Etymologie religijno-kulturową i pochodzenie językowe imion ustalono w oparciu o opracowania M. Malec [1994], J. Bubaka [1993], H. Frosa i F. Sowy [1997-2007] oraz słowniki W. Janowowej et al. [1991], A.W. Superanskiej [1998], A.N. Tichonowa et al. [1995]. Pomocne okazały się także prawosławne kalendarze - wydawnictwa Warszawskiej Metropolii Prawosławnej [2009] oraz Patriarchatu Moskiewskiego [1998]. 
Zaprezentowane dane wskazują na wyraźną przewagę imion pochodzenia greckiego. Drugie miejsce, wedle liczby imion, zajmują imiona łacińskie, tuż za nimi sytuują się imiona semickie. Listę zamykają imiona słowiańskie oraz jedno imię proweniencji egipskiej (Mojżesz). Mając na uwadze sumę wszystkich użyć, ilość imion semickich przewyższa odsetek antroponimów łacińskich. Taki stan rzeczy wynika przede wszystkim z popularności w omawianym okresie trzech imion hebrajskich: Jan, Józef i Michat.

d) imiona dzieci z rodzin urzędników i wojskowych - frekwencja

Chłopców urodzonych $\mathrm{w}$ rodzinach prawosławnych (takich przypadków było 170) nazwano imionami: Николай (21), Александр (17), Владимир (17), Сергий/Сергей (12), Иван/Иоанн (9), Георгий (8), Михаил (8), Павел (8), Петр (8), Алексий/Алексей (6), Евгений (6), Константин (6), Василий (5), Иосиф (4), Анатолий (3), Леонид (3), Андрей (2), Антоний/Антон (2), Борис (2), Григорий (2), Илия (2), Ипполит (2), Феодор (2) oraz jednokrotnie Авксентий, Адам, Аркадий, Арсений, Викентий, Виктор, Всеволод, Глеб, Донат, Кирилл, Никандр, Симеон, Стефан, Феодосий, Филипп.

Popularność zacytowanych antroponimów w znacznej mierze jest zbieżna z zestawieniem frekwencyjnym imion rodowitych bielszczan. Chociaż w innej kolejności, to imiona: Николай, Александр, Владимир, Иван/ Иоанн, Михаил, Павел należą do najczęściej wybieranych w obu grupach. Wyjątkiem może być imię Иocu $\oint$, które zajęło wysoką pozycję tylko wśród mieszczan i szlachty. Większość imion mało popularnych ma podobny status w obu zestawieniach (np. Авксентий, Виктор, Симеон, Стефан і in.). Nieco większą aktywność wśród bielszczan rodowitych przejawiają natomiast imiona Антоний, Григорий і Феодор.

\subsection{Imiona prawosławne żeńskie}

\section{a) popularność imion}

W imiennictwie żeńskim najczęściej nadawano imiona: Мария (64), Анна (47), Вера (30), София (28), Александра (25), Надежда (24), Ольга (20), Евгения (18). Mniej licznie wystąpiły: Елена (13), Лидия (13), Анастасия (11), Елизавета/Елисавета (10), Стефанида/Степанида (7), Иулия/Юлия (6), Любовь (6), Наталия (6). Najmniejszą popularnością cieszyły się imiona: Евдокия (4), Екатерина (4), Зиновия (4), Антонина (3), Варвара (3), Домника (3), Ксения (3), Марфа (2), Мелания (2), Нина (2), Олимпиада (2), Феврония (2), w tym jednokrotnie nadane: Валентина, Виктория, Галина, Зоя, Иулиания, Иулитта, Клавдия, Лукия, Марина, Матрона, Милича, Пелагия, Татиана. 
b) udział imion ze stanowiska motywacji religijno-kulturowej

\begin{tabular}{|c|c|c|}
\hline Źródła imion & Liczba imion & Liczba użyć imion \\
\hline Imiona biblijne $\mathrm{ST}$ & $1(2,4 \%)$ & $47(12,5 \%)$ \\
\hline Imiona biblijne NT & $5(12,2 \%)$ & $90(24,0 \%)$ \\
\hline Imiona świętych starochrześcijańskich (do V w.) & $33(80,5 \%)$ & $217(57,9 \%)$ \\
\hline Imiona świętych średniowiecza & $2(4,9 \%)$ & $21 \quad(5,6 \%)$ \\
\hline Razem & $41(100 \%)$ & $375(100 \%)$ \\
\hline
\end{tabular}

Dane zamieszczone w powyższej tabeli wskazują na dominację imion nawiązujących do świętych okresu starochrześcijańskiego. Drugie miejsce zajmują antroponimy motywowane imionami biblijnymi zaczerpniętymi z Nowego Testamentu. Imiona świętych średniowiecza oraz imiona biblijne starotestamentowe są reprezentowane mniej licznie. Zajmują one różne pozycje w zależności od przyjętej metody - w zakresie liczby imion odsetek imion średniowiecznych jest dwa razy wyższy w porównaniu z udziałem imion zaczerpniętych ze Starego Testamentu ${ }^{8}$. Przy uwzględnieniu liczby wszystkich aktów nominacyjnych ma miejsce sytuacja odwrotna. Jej przyczynę należy upatrywać w dużej popularności imienia Anna.

\section{c) udział imion ze względu na pochodzenie językowe}

Ze względu na przynależność językową, podział imion nadanych dziewczynkom ochrzczonym w bielskich parafiach prawosławnych przedstawia się następująco:

\begin{tabular}{|c|c|c|}
\hline Pochodzenie językowe imion & Liczba imion & Liczba użyć imion \\
\hline semickie (hebrajskie, aramejskie) & $4 \quad(9,7 \%)$ & $123(32,8 \%)$ \\
\hline greckie & $22(53,6 \%)$ & $205(54,7 \%)$ \\
\hline łacińskie & $11(26,8 \%)$ & $23(6,1 \%)$ \\
\hline greckie lub łacińskie & $2 \quad(4,9 \%)$ & $3(0,8 \%)$ \\
\hline słowiańskie & $2(4,9 \%)$ & $21 \quad(5,6 \%)$ \\
\hline Razem & $41(100 \%)$ & $375(100 \%)$ \\
\hline
\end{tabular}

Podobnie jak w imiennictwie męskim, w grupie antroponimów żeńskich dominują imiona o proweniencji greckiej. Stanowią one, niezależnie od przyjętej rachuby, ponad połowę całego zbioru. Uwzględniając liczbę imion,

8 Chociaż liczebnie jest to ilość zbliżona, bo wynosi $2: 1$. 
dalsze miejsca zajmują kolejno imiona wywodzące się z języka łacińskiego, języków semickich oraz ex aequo imiona grecko-łacińskie ${ }^{9}$ i słowiańskie (w tym imię Olga będące wczesnym zapożyczeniem z języków skandynawskich). Analizując zasób imion żeńskich z punktu widzenia liczby wszystkich ich użyć, drugie miejsce zajmują imiona semickie. Pozostałe antroponimy cechuje wyraźnie mniejsza frekwencja.

\section{d) imiona dzieci z rodzin urzędników i wojskowych - frekwencja}

W nominacji dziewczynek, pochodzących z rodzin urzędników i wojskowych, ochrzczonych w bielskich parafiach prawosławnych (163 przypadki) zastosowano następujące imiona: Мария (22), Александра (14), Ольга (14), Вера (13), Надежда (11), Елизавета/Елисавета (9), Анна (8), Елена (8), Любовь (6), Людмила/ Людмилла (6), Татиана (6), Екатерина (5), Зинаида (4), София (4), Евгения (3), Лидия (3), Пелагия (3), Анастасия (2), Галина (2), Ксения (2), Лариса/Ларисса (2), Наталия (2), Нина (2), jednokrotnie: Агафия, Валентина, Евфросиния, Зоя, Ирина, Кира, Клавдия, Леонилла, Мариамна, Марина, Серафима, Фекла.

Porównując zasób imion chrzestnych dziewczynek urodzonych w rodzinach rdzennych mieszkańców miasta ze zbiorem obejmującym córki funkcjonariuszy państwowych, należy odnotować, że w obu przypadkach mamy do czynienia z podobnym zestawem imion cieszących się w omawianym okresie dużą popularnością. Oprócz imienia Мapuя, które wystąpiło na 1. pozycji na obydwu listach, wysokie miejsca w obu rankingach zajmuja antroponimy Александра, Ольга, Вера, Надежда, Анна. Natomiast imiona Cо$\oint$ фия, Евгения, często nadawane wśród rodowitych bielszczanek, w rodzinach „mundurowych” należą do antroponimów o zdecydowanie niższej frekwencji. Fluktuacje w obu zestawieniach można zaobserwować również w stosunku do innych imion. W rodzinach funkcjonariuszy państwowych i wojskowych rzadziej występują imiona: Лидия, Пелагия, Анастасия. Odwrotną sytuację obserwujemy w odniesieniu do antroponimów Eлисавета, Любовь, Татиана, Екатерина і іn.

\subsection{Uwagi o nadawaniu imion prawosławnych}

Jak już wspomniano wyżej, w Kościele prawosławnym na chrzcie nadaje się tylko jedno imię ${ }^{10}$. Inną, typową dla obrządku wschodniego regułą jest

9 Chodzi tu o imiona Татиана, Феврония, dla których różne źródła podają rozbieżną etymologię.

10 We współczesnych zapisach metrykalnych można wprawdzie zaobserwować obecność 
wybieranie nowo narodzonym dzieciom imion chrzestnych ${ }^{11}$ posiadających wyłącznie motywację religijną. W badanym materiale zasada ta jest bezwzględnie przestrzegana - wszystkie antroponimy poświadczone są w kanonicznych wykazach imion. Ich zasadniczy filar tworzą imiona świętych obszaru śródziemnomorskiego (semickie, greckie, łacińskie).

Warto w tym miejscu zwrócić uwagę na imiona słowiańskie, upowszechnione wśród członków dynastii panujących w Europie wschodniej i południowo-wschodniej (Bałkany) w epoce średniowiecza. Przyjmując chrzest, osoby te najczęściej otrzymywały inne imiona, znane już w wiekach wcześniejszych i związane z dziedzictwem chrześcijańskim. Nadanie nowego imienia podkreślało zmianę w życiu duchowym władcy i całego narodu. Było to, teologicznie rzecz ujmując, powtórne narodzenie się, „narodzenie się z wody i Ducha” [por. J 3,5]. Obecność obu imion odnotowują m.in. cerkiewne kalendarze prawosławne, np.: блгв. князь Борис (в крещении Роман) страстотерпеч; блгв. чарь Борис (в крещении Михаил) Болгарский; равноап. вел. князь Владимир (в крещении Василий); блгв. князь Всеволод (в крещении Гавриил) Новгородский, Псковский; блгв. князь Глеб (в крещении Давид) страстотерпеч; блаж. Милища (в крещении Евфросиния) княгиня Сербская; равноап. вел. княгиня Российккая Ольга (в крещении Елена). Nie we wszystkich przypadkach imiona rodzime były zastępowane imionami przyniesionymi, nр.: блгв. князь Владимир Ярославич Новгородский; блгв. князь Вячеслав Чешский, страстотерпеч; блгв. князь Глеб Владимирский; ми. княгиня Людмила Чешская ${ }^{12}$. W tego typu przypadkach praktyka cerkiewna dopuszcza zastosowanie imienia słowiańskiego nawet wówczas, gdy władca (lub członek jego rodziny) dokonał zmiany imienia rodzimego na chrześcijańskie.

W metrykach jednej z parafii prawosławnych pojawiło się imię Buкmория, które w świadomości wiernych tego wyznania jest postrzegane jako typowe dla kalendarza polsko-łacińskiego, a obce tradycji wschodniej. Nie pojawia się ono w spisach świętych „europejskiego prawosławia” - nie notuje go Kalendarz prawosławny (wydawnictwa Warszawskiej Metropolii, 2009), Православный иерковный календарь (wydawnictwa Patriarchatu Moskiewskiego, 1998), Spis imion prawosławnych $w$ brzmieniu pol-

dwóch imion, aczkolwiek jedno z nich nie jest imieniem chrzestnym w dosłownym znaczeniu tego słowa. Zagadnieniu temu poświęciłem artykuł pt. Czy nadawane wspótcześnie „stare” imiona prawostawne zawsze sa zamierzonym przejawem powrotu do tradycji? [2016].

11 Zob. poprzedni przypis.

12 Przykłady pochodzą z kalendarzy prawosławnych wydanych przez Patriarchat Moskiewski [1998] oraz Warszawską Metropolię [2009]. 
skim i staro-cerkiewno-stowiańskim [2011] oraz Trebnik [1925]. Stąd, jak można przypuszczać, powstało przekonanie o katolickim charakterze tego imienia. Niemniej, św. męcz. Wiktoria występuje w II tomie Полного месяиеслова Востока autorstwa arcybiskupa Sergiusza Spasskiego [Спасский 1876 [1997]]. Wspomnienie liturgiczne świętej przypada na 25 V, 1 VI, $24 \mathrm{X}$ według starego stylu. Należy więc stwierdzić, że obecność omawianego imienia w metrykach Kościoła prawosławnego jest uzasadniona.

\subsection{Formy językowe imion prawosławnych}

Kilka słów należy poświęcić formom językowym imion wykorzystanych w nominacji prawosławnych chłopców i dziewczynek. W zdecydowanej większości zapisów zachowana jest kanoniczna postać imienia (Авксентий, Василий, Евстафий, Иосиф, Николай, Стефан; Анастасия, Домника, Мелания, Пелагия, Татиана, Феврония itd.). Nie jest to jednak regułą bezwzględną, chociaż przepisy cerkiewne wyraźnie mówią, w jaki sposób winny być zapisywane imiona chrzestne: „имена рожденных писать согласно святцам, а не по устному произношению их в обыденной речи: следует писать Иоаннъ, а не Иванъ, Корнилий, а не Корней (...)" [Булгаков 1913 [1993], 973-974]. Jak się zatem wydaje, utrzymanie w metrykach obrządku bizantyjskiego form imion obowiązujących w sferze sakralnej nie powinno być problematyczne, chociażby ze względu na bliską więź tej konfesji z rosyjskojęzycznym kręgiem kulturowym. Wśród analizowanych notacji wystąpiło jednak kilka form, posiadających w antroponimii rosyjskiej status „oficjalnych świeckich”: Антон (por. cerk. Антоний), Алексей (por. cerk. Алексий), Иван (por. cerk. Иоанн), Сергей (por. cerk. Сергий), Яков (por. cerk. Иаков); Елизавета (por. cerk. Елисавета), Степанида (por. cerk. Стефанида), Юлия (por. cerk. Иулия). Ponadto zanotowano dwie odmianki z geminacją spółgłoskową - Лapucca (por. cerk. Лapuca), Людмилла (por. cerk. Людмила), wykazujące znamiona hiperpoprawności. Niewykluczone, że warianty te inspirowane były innymi imionami, w których geminanta występuje w wersji kanonicznej, np. Василисса, Bасса, Хариесса; Иовилла, Кирилла, Леонилла, Марионилла, Неонилла, Прискилла, Феонилла, Филонилла ${ }^{13}$.

13 Przykłady zaczerpnięto z kalendarza cerkiewnego wydawnictwa Patriarchatu Moskiewskiego [1998]. Co ciekawe, w Spisie imion prawosławnych [2011] imię Неонила występuje z pojedynczym $\Omega$, natomiast Лapucca - z podwójnym $c$. 


\section{Imiona chrzestne bielszczan wyznania rzymskokatolickiego}

W identycznym niemal okresie, bo w latach 1890-1908, w parafii rzymskokatolickiej ochrzczono 399 dzieci (189 chłopców i 210 dziewczynek) z bielskich rodzin szlacheckich, mieszczańskich i włościańskich. Nadano przy tym 190 imion męskich i 213 żeńskich. Oznacza to, że w czterech przypadkach zastosowano model dwuimienny. Tradycja nadawania na chrzcie więcej niż jednego imienia, chociaż nieobca tradycji łacińskiej, na badanym terenie jak wynika z przedstawionych danych - w interesującym nas przedziale czasowym obecna jest $\mathrm{w}$ stopniu minimalnym ${ }^{14}$. W nominacji wykorzystano 43 imiona męskie i 44 żeńskie.

\subsection{Imiona rzymskokatolickie męskie}

\section{a) popularność imion}

W męskim systemie imienniczym bielskich katolików największym uznaniem cieszyło się imię Иосиф (29 nadań). Często korzystano ponadto z imion Александр (15), Владислав (14) оraz Иван (14). Mniej chętnie nadawano imiona Антон (11), Эдвард/Эдуард (10), Адам (9), Станислав (9), Вачлав (8), Павел (6), Сигизмунд (6), Казимир (5). Do rzadkich lub bardzo rzadkich należy zakwalifikować antroponimy: Бронислав (4), Викентий (4), Франи/Франциск/Францишек/Францишк (4), Болеслав (3), Игнатий (3), Мечислав (3), Николай (3), Витольд (2), Евгений/Евгении (2), Константин (2), Михаил (2), Петр (2), Ромуальд (2) oraz wykorzystane jeden raz: Адольф, Альфред, Виктор, Владимир, Генрих, Ипполит, Конрад, Ксаверий, Леон, Людвик, Наполеон, Пиус, Пржемьислав, Райнольд, Томаш, Цезарии, Шимон, Эдмунд15.

\section{b) udział imion ze stanowiska motywacji religijno-kulturowej}

W zasobie niepowtarzających się antroponimów, najwyższy odsetek zanotowano dla imion motywowanych postaciami świętych epoki średniowiecza. Nieco mniej imion nawiązuje do świętych starochrześcijańskich. Trzecie miejsce zajęły imiona, których nosiciele nie mają swoich patronów wśród po-

$14 \mathrm{~W}$ związku ze znikomym odsetkiem zjawiska wieloimienności zrezygnowano z oddzielnej prezentacji zestawień frekwencyjnych dla tego typu nominacji. Nie wpływa ona bowiem na wnioski płynące z analizy przedstawionego materiału.

15 Jak można zauważyć, operując stosunkowo ubogim (chociaż wysoce reprezentatywnym) materiałem źródłowym, czasami niełatwo jest dokonać wyraźnego zaszeregowania imion do poszczególnych grup według kryterium popularności. 


\begin{tabular}{|c|c|c|}
\hline Źródła imion & Liczba imion & Liczba użyć imion \\
\hline Imiona biblijne $\mathrm{ST}$ & $3(7,0 \%)$ & $40(21,0 \%)$ \\
\hline Imiona biblijne NT & $5(11,6 \%)$ & $24(12,6 \%)$ \\
\hline Imiona świętych starochrześcijańskich (do V w.) & $12(29,9 \%)$ & $45(23,7 \%)$ \\
\hline Imiona świętych średniowiecza & $16(37,2 \%)$ & $66(34,7 \%)$ \\
\hline Inne imiona (bez św. lub tylko błogosł.; dysk.) & $7(16,3 \%)$ & $15(7,9 \%)$ \\
\hline Razem & $43(100 \%)$ & $190(100 \%)$ \\
\hline
\end{tabular}

staci kanonizowanych przez Kościół zachodni ${ }^{16}$. Wśród imion biblijnych antroponimy zaczerpnięte z Nowego Testamentu nieznacznie przeważają nad imionami starotestamentowymi. Zestawienie uwzględniające liczbę wszystkich użyć imion również pozwala wnioskować, że najczęściej korzystano z imion świętych średniowiecznych, a drugie miejsce zajmują imiona świętych okresu starochrześcijańskiego. Rzadziej korzystano natomiast z imion biblijnych - staro- i nowotestamentowych. Antroponimy pozbawione motywacji stricte religijnej cechują się niską frekwencją użycia.

\section{c) udział imion ze względu na pochodzenie językowe}

Kwestia przynależności językowej antroponimów męskich wyekscerpowanych z metryk parafii rzymskokatolickiej przedstawia się w sposób następujący:

\begin{tabular}{|c|c|c|}
\hline Pochodzenie językowe imion & Liczba imion & Liczba użyć imion \\
\hline semickie (hebrajskie, aramejskie) & $6(13,9 \%)$ & $56(29,5 \%)$ \\
\hline greckie & $6(13,9 \%)$ & $24(12,6 \%)$ \\
\hline łacińskie & $10(23,2 \%)$ & $34(17,9 \%)$ \\
\hline germańskie & $10(23,2 \%)$ & $25(13,1 \%)$ \\
\hline litewskie lub germańskie & $1(2,3 \%)$ & $2(1,0 \%)$ \\
\hline słowiańskie & $9(20,9 \%)$ & $48(25,3 \%)$ \\
\hline inne & $1 \quad(2,3 \%)$ & $1(0,5 \%)$ \\
\hline Razem & $43(100 \%)$ & $190(100 \%)$ \\
\hline
\end{tabular}

$16 \mathrm{~W}$ grupie tej znalazły się również imiona związane z wybitnymi przedstawicielami obrządku łacińskiego czczonymi przez wiernych tej konfesji, ale znajdującymi się w gronie błogosławionych. Tu należy ponadto umieścić imiona świętych, których kult poświadczony jest $\mathrm{w}$ literaturze hagiograficznej $\mathrm{w}$ sposób niedostateczny lub pozostaje sprawą dyskusyjną. 
Ze względu na liczbę imion, najwyższą produktywność wykazują imiona łacińskie, germańskie oraz rodzime imiona pochodzenia słowiańskiego. Imiona semickie i greckie były wykorzystywane rzadziej, sporadycznie zaś posłużono się antroponimami o nieustalonej etymologii językowej ${ }^{17}$. Zestawienie uwzględniające sumę wszystkich użyć imion otwierają imiona semickie. Na ich pozycję wpłynęła znaczna popularność w interesującym nas okresie imion Józef, Jan oraz - w nieco mniejszym stopniu - Adam. Stosunkowo często stosowano także imiona słowiańskie (2. miejsce). Na dalszych pozycjach znalazły się kolejno antroponimy o proweniencji łacińskiej, germańskiej, greckiej i innej.

d) imiona dzieci z rodzin urzędników i wojskowych - frekwencja

Podobnie jak w metrykach prawosławnych, również w aktach parafii rzymskokatolickiej poświadczona jest pewna liczba zapisów chrztów dzieci urodzonych w rodzinach urzędników i wojskowych. Wśród nowo narodzonych chłopców stwierdzono 46 takich przypadków. Nadano przy tym 48 imion męskich: Александр (15), Иван (7), Иосиф (6), Казимир (4), Станислав (4), Антон (3), Болеслав (3), Вачлав (3), Виктор (2), Мечислав (2), Петр (2), Ромуальд (2), Сигизмунд (2), Эдуард (2), oraz pojedynсzо: Бронислав, Валериян, Викентий, Владислав, Генрих, Евгений, Збигнев, Игнатий, Леон, Павел, Роман, Чеслав, Эдмунд, Ярослав.

Jak pokazuje zestawienie, trzy pierwsze imiona: Александр, Иван, Иосиф - należą do najpopularniejszych także w łacińskim imiennictwie męskim rodowitych bielszczan. Jednocześnie można zauważyć, że w tym zasobie najwyższac pozycję zajmuje imię Александp, na liście poprzedniej - Иосиф. Proporcjonalnie częściej w rodzinach urzędników i mundurowych pojawiły się imiona Александр, Болеслав, Иван, Казимир, Станислав. Odwrotna sytuacja dotyczy imienia Владислав. W tym miejscu wystąpiło ono zaledwie jeden raz, chociaż w rodzinach „cywilnych” należało do zbioru najczęściej używanych.

\subsection{Imiona rzymskokatolickie żeńskie}

\section{a) popularność imion}

W nominacji żeńskiej najczęściej korzystano z imion: Мария (22), Сoфия (15), Янина (15) і Мариянна/Марианна (14). Mniejszym zaintereso-

17 Mowa tu o imieniu Witold, definiowanym zazwyczaj jako litewskie lub germańskie [Fros, Sowa 2007, 198] oraz o imieniu Ksawery wywodzącym się od nazwy miejscowości w Królestwie Nawarry (obecnie Hiszpania), z której pochodził św. Franciszek Ksawery. 
waniem cieszyły się: Анна (12), Иозефа (11), Виктория (10), Елена/Гелена (9), Ядвига (9), Аделия/Аделя (8), Александра (8), Бронислава (8), Антонина (6), Емилия/Эмилия (6), Леокадия (5), Стефания (5). Do imion rzadkich i bardzo rzadkich należały: Ева/Евва (4), Болеслава (3), Елеонора (3), Каролина (3), Станислава (3), Амелия (2), Аполония (2), Богумила (2), Ванда (2), Казимира/Kazimira (2), Камилия/Камилла (2), Леонтина/Леонтына (2), Маргарита/Малгоржата (2), Павлина (2), Феличия (2), Франциска/ Францишка (2) oraz wykorzystane jednokrotnie Владислава, Евгения, Елисавета, Констанция, Людвика, Михалина, Никодема, Пелягия, Розалия, Северина, Теодозия, Теофиля.

b) udział imion ze stanowiska motywacji religijno-kulturowej

\begin{tabular}{|c|c|c|}
\hline Źródła imion & Liczba imion & Liczba użyć imion \\
\hline Imiona biblijne $\mathrm{ST}$ & $2(4,5 \%)$ & $16(7,5 \%)$ \\
\hline Imiona biblijne NT & $2(4,5 \%)$ & $23(10,8 \%)$ \\
\hline Imiona świętych starochrześcijańskich (do V w.) & $16(36,4 \%)$ & $73(34,3 \%)$ \\
\hline Imiona świętych średniowiecza & $7(15,9 \%)$ & $37(17,4 \%)$ \\
\hline Inne imiona (bez św. lub tylko błogosł.; dysk.) & $17(38,6 \%)$ & $64(30,0 \%)$ \\
\hline Razem & $44(100 \%)$ & $213(100 \%)$ \\
\hline
\end{tabular}

Analiza powyższego zestawienia prowadzi do interesujących wniosków, zwłaszcza w zakresie liczby niepowtarzających się antroponimów. Zwraca uwage fakt, że w omawianym okresie najchętniej nadawano imiona nieposiadające stricte religijnej motywacji ${ }^{18}$. Nieco mniej popularne były imiona świętych starochrześcijańskich. Antroponimy motywowane świętymi epoki średniowiecza zajęły 3 . miejsce. Na peryferiach frekwencyjnych znalazły się imiona biblijne. Kolejność poszczególnych grup imion na liście uwzględniającej liczbę wszystkich ich użyć jest inna. Wprawdzie imiona występujące na dwóch pierwszych miejscach również cechują się zbliżoną produktywnością, to jednak ich kolejność jest w tym przypadku odwrotna (patrz tabela).

18 Zob. przypis nr 16. Część imion tego podzbioru utworzono od antroponimów męskich posiadających motywację religijną (Kazimira - od Kazimierz, Janina - od Jan itd.). 
c) udział imion ze względu na pochodzenie językowe

Podział wykorzystanych imion żeńskich z uwzględnieniem genezy językowej kształtuje się następująco:

\begin{tabular}{|c|c|c|}
\hline Pochodzenie językowe imion & Liczba imion & Liczba użyć imion \\
\hline semickie (hebrajskie, arabskie) & $8(18,2 \%)$ & $69(32,4 \%)$ \\
\hline greckie & $12(27,3 \%)$ & $51(23,9 \%)$ \\
\hline łacińskie & $12(27,3 \%)$ & $49(23,0 \%)$ \\
\hline germańskie & $5(11,4 \%)$ & $23(10,8 \%)$ \\
\hline słowiańskie & $6(13,6 \%)$ & $19(8,9 \%)$ \\
\hline litewskie lub słowiańskie (polskie) lub germańskie & $1(2,3 \%)$ & $2(0,9 \%)$ \\
\hline Razem & $44(100 \%)$ & $213(100 \%)$ \\
\hline
\end{tabular}

Zaprezentowane zestawienia wskazują na wyraźną dominację imion powstałych na gruncie kultury śródziemnomorskiej. W zakresie liczby imion pierwszą pozycję zajęły jednocześnie antroponimy pochodzenia greckiego i łacińskiego, kolejne miejsca - imiona semickie, słowiańskie, germańskie oraz imię Wanda o nieustalonej jednoznacznie etymologii. W zakresie liczby użyć imion największy odsetek zanotowano wśród antroponimów o genezie semickiej. Taka sytuacja jest konsekwencją dużej popularności imion hebrajskich Maria, Anna oraz imion Józefa i Janina utworzonych od antroponimów męskich.

\section{d) imiona dzieci z rodzin urzędników i wojskowych - frekwencja}

W rodzinach urzędników i wojskowych zostało ochrzczonych 65 dziewczynek. W ich nominacji wykorzystano 68 imion: Мариянна/Марианна (9), Станислава (6), Леокадия (5), София (5), Виктория (4), Мария (4), Ядвига (4), Янина (4), Антонина (2), Паулина (2), Гелена (2), Иозефа (2), Каролина (2), Михалина (2), Стефания (2) oraz Аделя, Александра, Аполония, Бронислава, Ванда, Владислава, Габриеля, Галина, Ева, Леонтина, Меляния, Сабина, Фелииия (po 1 nadaniu).

Jedynie imię Мариянна/Марианна można zakwalifikować jako najczęściej wykorzystywane w obydwu przypadkach. Proporcjonalnie częściej w tym zestawieniu pojawiają się, oprócz zacytowanego wyżej, imiona $\mathrm{Cma-}$ нислава і Леокадия. Mniejszym uznaniem w rodzinach urzędników i mundurowych cieszyły się Aделя, Александра, Бронислава, Елена/Гелена oraz Мария. Ostatni przykład może być nieco zaskakujący, ponieważ imię to wśród dzieci rdzennych mieszkańców wystąpiło na 1. miejscu. 


\subsection{Uwagi o nadawaniu imion rzymskokatolickich}

Model dwuimienny w nazewnictwie bielskich katolików pojawia się w latach 1890-1908 sporadycznie. Wśród rodowitych bielszczan występuje 4 razy, natomiast pięciokrotnie użyto na chrzcie dwóch imion w odniesieniu do dzieci urzędników i wojskowych. Dwukrotnie odnotowano zestawienie Янина-Мария, pozostałe egzemplifikacje poświadczone są pojedynсzо: Антон-Иван, Игнатий-Ромуальд, Пржемьлслав-Витольд; Александра-Ядвига, Габриеля-Станислава, Мария-Антонина, Аделя-Михалина. Użyte w nominacji dwuimiennej antroponimy występują na różnych miejscach w zestawieniu ogólnym. Trudno więc w analizowanym kontekście mówić o jakichkolwiek tendencjach decydujących o wyborze tych właśnie imion, bez względu na to, czy wystąpiły na pierwszej, czy na drugiej pozycji.

\subsection{Formy językowe imion rzymskokatolickich}

Konsekwencją przynależności Bielska do Cesarstwa Rosyjskiego było stosowanie w badanym okresie języka rosyjskiego w sferze administracyjno-urzędowej. Dla Kościoła rzymskokatolickiego język ten był kulturowo obcy. Formy graficzno-brzmieniowe imion zanotowanych wśród bielskich katolików zależały m.in. od sposobu transliteracji na alfabet cyrylicki. W celu usprawnienia zapisu $\mathrm{w}$ języku rosyjskim imion mieszkańców nieprawosławnych i nierosyjskojęzycznych wydano na początku XX wieku w Sankt Petersburgu opracowanie pt. Список всех имеюшихся в обиходе у римско-католиков крестных имен [za: Abramowicz 1993, 32-33]. Autorzy spisu zawierającego zasady adaptacji imion do norm języka rosyjskiego obligują do stosowania rosyjskich ekwiwalentów w przypadku, gdy dane imię należy do zasobu mian ogólnochrześcijańskich. W sytuacji braku właściwych odpowiedników imiona katolickie należy zapisywać w maksymalnie zbliżonym brzmieniu $\mathrm{w}$ języku rosyjskim z jednoczesnym podaniem $\mathrm{w}$ nawiasie oryginalnej formy graficznej.

Badany materiał poświadcza użycie w notacji różnych rozwiązań. Problemu nie stanowił zapis antroponimów językowo tożsamych ${ }^{19} \mathrm{w}$ obu obrządkach: Адам, Валериян ${ }^{20}$, Виктор, Леон ${ }^{21}$, Роман, Ярослав; Анна,

19 W imionach męskich jedyną cechą różnicującą może być akcent.

20 Dopuszczono się w tym miejscu drobnego błędu w zapisie imienia, poprawną powinna być forma Валериан (zob. np. Православный иерковный календарь 1998, 75).

21 Imię Леон w dyptychach świętych prawosławnych występuje w charakterze drugiego miana św. Leoncjusza biskupa Adrianopola (св. Леонтия Адрианопольского), zob. np. Kalendarz prawostawny 2009, 159. 
Антонина, Виктория. Część imion podano w brzmieniu obowiązującym w Kościele wschodnim, np. Александр, Викентий, Владимир, Евгении ${ }^{22}$, Игнатий, Иосиф, Ипполит, Константин, Михаил, Николай, Павел, Петр; Галина, Ева ${ }^{23}$, Евгения, Елена, Елисавета, Емилия, Маргариma, Мария, София. W dwóch przykładach posłużono się ekwiwalentem rosyjskim używanym w obiegu prawno-administracyjnym (Антон, Иван). Natomiast w przypadku zapisu imion kalendarza zachodniego (z zachowaną motywacja religijną lub jej pozbawionych), które nie występują w dyptychach świętych prawosławnych, dążono do możliwie najwierniejszego oddania brzmienia oryginalnego (polskiego), uwzględniając jednocześnie normy fonetyczne, gramatyczne i ortograficzne języka rosyjskiego. Najczęściej dotyczyło to imion germańskich (Адольф, Альфред, Конрад, Людвик, Райнольд, Ромуальд, Эдмунд; Аделия/Аделя, Амелия, Людвика, Ядвига) oraz słowiańskich (Болеслав, Бронислав, Вачлав, Владислав, Збигнев, Казимир, Мечислав, Станислав, Чеслав; Богумила, Болеслава, Бронислава, Владислава, Казимира ${ }^{24}$, Станислава), rzadziej - łacińskich (Наполеон, Пиус; Камилия/Камилла, Сабина) і innych (Витольд, Ксаверий; Аполония, Ванда, Елеонора, Леокадия). Kilka antroponimów przejętych z zachodnio- i południowoeuropejskich systemów imienniczych zapisano $\mathrm{w}$ postaci ekwiwalentu rosyjskiego fonetycznie bliskiego formie $\mathrm{w}$ języku oryginału, z pominięciem brzmienia polskiego (Генрих, Сигизмунд, Франи/Франииск, Эдуард; Франииска). Ostatnią wreszcie grupę reprezentują imiona z zachowaną fonetyką języka polskiego: Томаu, Франиишек/Францишк, Цезарии, Шимон, Эдвард; Гелена, Иозефа, Констаниия, Леонтына, Малгоржата, Мариянна/Марианна, Меляния, Михалина, Никодема, Пелягия, Стефания, Теодозия, Теофиля, Францишка, Эмилия. W przypadku tego ostatniego zbioru należałoby się zastanowić nad motywacją przyświecającą wyborowi takich właśnie form imion. Dlaczego nie zastosowano bardziej powszechnych ekwiwalentów w postaci odmianek już wyżej cytowanych, np. dla imion ,zachodnich” - Франциск/Франциска zamiast Францишек/Францишка, Эдуард zamiast Эдвард? W stosunku do imion żeńskich pochodnych od męskich można przecież z powodzeniem utworzyć formy słowotwórczo pochodne, np. Гавриила (wobec poświad-

22 Poświadczoną formę przypuszczalnie można tłumaczyć niedoskonałością zapisu, por. popr. Евгений.

23 Imię to zostało wykorzystane w nominacji czterokrotnie. Jeden raz wystąpiło w postaci Eвва, co należy uznać za przejaw hiperpoprawności.

$24 \mathrm{~W}$ jednym przykładzie mamy do czynienia z zapisem tego imienia alfabetem polskim. W 1926 roku dokonano modyfikacji w metryce, zamieniając zanotowane w $1900 \mathrm{r}$. imię męskie Казимиръ na żeńskie Kazimiera oraz słowa syn na córka. 
czonego Габриеля), Иосифа (wobec Иозефа), Никодима (wobec Никодемa) itp. Kwestią wymagającą wyjaśnienia pozostaje też użycie transliteracji polskich wariantów mimo istnienia odpowiednich form $\mathrm{w}$ kalendarzu rosyjskim (w liturgii rusko-bizantyjskiej): Томаш (por. Фома), Цезарии (por. Кесарий), Шимон (por. Симон); Гелена (por. Елена), Малгоржата (por. Маргарита), Мариянна/Марианна (por. Мариамна), Меляния (por. Мелания), Пелягия (por. Пелагия), Теодозия (por. Феодосия), Теофиля (por. Феофила), Эмилия (por. Емилия). Występowanie przykładów w brzmieniu polskim przypuszczalnie można wiązać z życzeniem rodziców, wyrażających wolę zapisania imienia dziecka w takiej właśnie postaci. Nie jest wykluczone, że czyniono tak z pobudek patriotycznych.

\section{Najpopularniejsze imiona chrzestne bielszczan $\mathrm{w}$ aspekcie zróżnicowania wyznaniowego}

Poniższe zestawienie przedstawia pierwszą dziesiątkę najpopularniejszych imion:

\begin{tabular}{|r|l|l|l|l|}
\hline \multirow{2}{*}{} & \multicolumn{2}{|c|}{ Imiona męskie } & \multicolumn{2}{c|}{ Imiona żeńskie } \\
\cline { 2 - 5 } & \multicolumn{1}{|c|}{ prawosławne } & \multicolumn{1}{|c|}{ katolickie } & prawosławne & \multicolumn{1}{c|}{ katolickie } \\
\hline 1. & Иван/Иоанн & Иосиф & Мария & Мария \\
\hline 2. & Александр & Александр & Анна & София \\
\hline 3. & Владимир & Владислав & Вера & Янина \\
\hline 4. & Иосиф & Иван & София & $\begin{array}{l}\text { Мариянна/ } \\
\text { Марианна }\end{array}$ \\
\hline 5. & Павел & Антон & Александра & Анна \\
\hline 6. & Михаил & Эдвард/Эдуард & Надежда & Иозефа \\
\hline 7. & Николай & Адам & Ольга & Виктория \\
\hline 8. & Петр & Станислав & Евгения & Елена/Гелена \\
\hline 9. & Константин & Вацлав & Елена & Ядвига \\
\hline 10. & Антоний & Павел, & Лидия & $\begin{array}{l}\text { Аделия/Аделя, } \\
\text { Александра, } \\
\text { Бронислава }\end{array}$ \\
\hline
\end{tabular}

W imiennictwie męskim pięć najczęściej wybieranych imion obecnych jest $\mathrm{w}$ zestawieniach frekwencyjnych zarówno w Kościele wschodnim, jak i zachodnim. W tej grupie imię Александp w obu przypadkach znajduje 
się na 2. miejscu. Imiona Иван/Иоанн і Павел wyższe pozycje zajmują $\mathrm{w}$ imiennictwie prawosławnym. Odwrotna sytuacja dotyczy imion Иосиф i Антон/Антоний. Należy zauważyć, że pięciu imion popularnych w metrykach Kościoła katolickiego nie stosuje się w nominacji w Cerkwi prawosławnej, ponieważ święci noszący te imiona występują jedynie w kalendarzu zachodnim. Należą do nich 3 imiona o proweniencji słowiańskiej (Вачлав, Владислав, Станислав) oraz 2 antroponimy pochodzenia germańskiego (Сигизмунд і Эдвард/Эдуард). Ponadto warto odnotować, że na 3. pozycji znalazły się imiona słowiańskie z jednakową częścią inicjalną Владимир і Владислав. Pierwsze - obecne w imiennictwie polskim i wschodniosłowiańskim, ale częściej kojarzone z kulturą chrześcijańskiego Wschodu za sprawą św. Włodzimierza księcia kijowskiego (X wiek), drugie - obecne przede wszystkim na gruncie polskim w związku z kultem Św. Władysława węgierskiego (XI wiek). Elementem łączącym oba te imiona są wspólne formy hipokorystyczno-deminutywne typu Wtadek, Władzio, Włodzio itd. Z tego powodu antroponimy Владимир і Владислав często są mylnie uznawane przez przeciętnych użytkowników języka jako „bardziej ruski, prawosławny” lub „bardziej polski, katolicki” wariant tego samego imienia.

W nominacji żeńskiej pięć najpopularniejszych imion wystąpiło na listach obu Kościołów. Imię Mapuя w obu zestawieniach figuruje na 1. pozycji. Wyższe miejsca w tradycji rusko-bizantyjskiej zajmują imiona Анна i Александра, bardziej popularne w obrządku łacińskim okazały się imiona София і Елена. Podobnie jak w nazewnictwie męskim, część antroponimów właściwa jest tylko jednej konfesji, a sporadyczna lub w ogóle niewystępująca w kalendarzu drugiego wyznania. Kwestię tę ilustrują imiona Bepa i Надежда, obecne wyłącznie wśród osób wyznania prawosławnego. Zdecydowanie częściej w tradycji wschodniej występuje imię Ольгa. Odwrotną sytuację należy stwierdzić w stosunku do imion Янина, Иозефа, Ядвига, Аделия/Aделя і Бронислава, nadawanych tylko w Kościele zachodnim.

\section{Podsumowanie}

Jak wynika z analizy przedstawionego materiału, czynnik konfesyjny w znacznym stopniu wpływa na zróżnicowanie imiennictwa mieszkańców tego samego obszaru. W przypadku systemu nazewniczego Bielska Podlaskiego na przełomie XIX i XX w. należy stwierdzić, że zasadniczy filar zasobu imion użytych w nominacji dzieci ochrzczonych w obu Kościołach stanowią antroponimy wywodzące się ze wspólnego dziedzictwa chrześcijańskiego. Jednocześnie prezentowane dane wykazują pewne różnice wynikające 
z przynależności rodziców dziecka do jednego z dwóch obrządków - prawosławnego lub rzymskokatolickiego. Dlatego obok imion ogólnochrześcijańskich wystąpiły antroponimy charakterystyczne tylko dla jednego wyznania (np. dla Kościoła łacińskiego - Генрих, Казимир, Пиус; Леокадия, Розалия, Ядвига; dla rusko-bizantyjskiego - Глеб, Матрона, Милица). Różnice uwidaczniają się także w zestawieniach frekwencyjnych poszczególnych grup wyznaniowych. Nierzadko popularność danego imienia jest zupełnie odmienna w zależności od obrządku.

W imiennictwie obu Kościołów różny jest procentowy udział imion rozpatrywanych z perspektywy genezy religijno-kulturowej oraz ich przynależności językowej. Do zasadniczych cech dyferencjujących należy odnieść przede wszystkim obecność wyłącznie w aktach parafii rzymskokatolickiej imion o proweniencji germańskiej, a także zdecydowanie większą produktywność względem metryk prawosławnych imion pochodzenia słowiańskiego.

Dostrzegalne są też inne rozbieżności. Zasób imion użytych w nominacji dzieci w Kościele prawosławnym całkowicie oparty jest o imiona świętych występujących w kalendarzu liturgicznym tego obrządku. Grupa antroponimów zanotowanych wśród bielskich katolików cechuje się natomiast obecnością imion pozbawionych motywacji stricte religijnej lub nawiązujących do postaci, których kult związany jest $\mathrm{w}$ większym stopniu z legendą niż z przekazami o charakterze hagiograficznym.

Atrybutem różnicującym obie grupy wyznaniowe jest ponadto wieloimienność - występująca jedynie w obrządku łacińskim, a obca tradycji rusko-bizantyjskiej. W analizowanym materiale odsetek nominacji dwuimiennych w Kościele rzymskokatolickim jest znikomy.

O częściowej odmienności zasobów imion bielskich katolików i prawosławnych w latach 1890-1909 zdecydował nie tylko zestaw zastosowanych antroponimów i ich frekwencja, ale także formy fonetyczno-ortograficzne.

W warstwie onimicznej znajduje odbicie kwestia przynależności państwowej miasta $\mathrm{w}$ interesującym nas okresie. Problem ten inaczej będzie postrzegany z punktu widzenia autochtonicznej ludności ruskiej, prawosławnej, a inaczej - ze strony społeczności polskiej, rzymskokatolickiej. Obrządek bizantyjski, wyznawany od wieków przez część społeczeństwa na Podlasiu w niemałym stopniu wpłynął na powiązania w sferze tradycji i kultury prawosławnych mieszkańców tego regionu z dziedzictwem duchowym obecnym w innych częściach Cesarstwa Rosyjskiego. Dla miejscowych katolików język rosyjski był już kulturowo obcy. Z tego m.in. powodu „integracja” tej drugiej grupy ludności ze światem dominującym na obszarze Imperium ograniczała się jedynie do niezbędnych dziedzin funkcjonowania społecznego. Jednocześnie dążono do zachowania swojej odrębności narodowej. Pobudkami 
natury patriotycznej należy bowiem tłumaczyć obecność w metrykach parafii rzymskokatolickiej znacznej ilości antroponimów słowiańskich nawiązujących do imion dynastycznych lub do imion polskich świętych. Nie zaskakuje też udział w zasobie imion obrządku łacińskiego imion pochodzenia germańskiego. Jak można przypuszczać, sięganie do nich przy nominacji nowo narodzonych dzieci było podyktowane dążeniem do zwrócenia się ku cywilizacji zachodniej i tym samym do zaakcentowania swojej alienacji wobec tradycji wschodniosłowiańskiej. Takiemu działaniu sprzyjał fakt niewystępowania imion germańskich w kalendarzu bizantyjsko-ruskim. Zamanifestowanie własnej tożsamości narodowej w istniejących uwarunkowaniach politycznych mogło być wyrażone także przez użycie „spolszczonych" wariantów imion chrzestnych, często pomimo istnienia usankcjonowanych odpowiedników.

\section{Literatura}

Abramowicz Z., 1993, Imiona chrzestne białostoczan w aspekcie socjolingwistycznym (lata 1885-1895), Białystok.

Borek H., 1978, Socjolingwistyczne aspekty imiennictwa, „Onomastica” XXIII, s. $163-175$.

Bubak J., 1993, Ksiega naszych imion, Wrocław.

Fionik D., 2011, Dzieje cerkiewne kościoła pokarmelickiego, „Бельскі гостінэць”, nr 2 (44), s. $12-34$.

Fionik D., 2015, Z dziejów bielskiej wojskowości w XIX wieku, „Бельскі гостінэць”, nr $2(52)$, s. $59-67$.

Fros H., Sowa S., 1997-2007, Księga imion i świętych, t. 1-6, Kraków.

Janowowa W., Skarbek A., Zbijowska B., Zbiniowska J., 1991, Stownik imion, Wrocław-Warszawa-Kraków.

Kalendarz Prawosławny 2009, Wydanie Warszawskiej Metropolii Prawosławnej.

Kosieradzki H., 1987, Bielsk Podlaski - dzieje miasta, Bielsk Podlaski.

Malec M., 1994, Imiona chrześcijańskie w średniowiecznej Polsce, Kraków.

Mazuruk K., Fionik D., 2003, Bielsk Podlaski - miasto pogranicza, Bielsk Podlaski-Białystok.

Mordań M., 2016, Czy nadawane wspótcześnie „stare” imiona prawostawne zawsze sa zamierzonym przejawem powrotu do tradycji?, „Acta Polono-Ruthenica”, t. XXI, s. 51-65.

Pismo Święte Starego i Nowego Testamentu, 1990, Poznań.

Sosna G., Fionik D., 1995, Dzieje Cerkwi w Bielsku Podlaskim, Białystok.

Spis imion prawostawnych $w$ brzmieniu polskim i staro-cerkiewno-stowiańskim, 2011, Warszawa. 
Булгаков С.В., 1913 [1993], Настольная книга для священно-иерковно-служителей, т. II, Москва.

Православный черковный календарь 1998, Издательство Московской Патриархии.

Семянчук Г., 2013, Горад Бельск $і$ яго жьихары ў 1914 годзе, „Бельскі гостінэць", nr 2 (48), s. 36-72.

Семянчук Г., 2015, Вайскойць у Бельску у 1897 годзе, „Бельскі гостінэць”, nr $2(52)$, s. $72-83$.

Соркіна I., 2011, Бельск у матэрыялах Літойскага дзяржаўнага гістарычнага архіва, „Бельскі гостінэць”, nr 2 (44), s. 57-59.

Спасский С., 1876 [1997], Полньй месячеслов Востока. Том II: Святой Восток, указатель 4, [online], http://azbyka.ru/otechnik/Sergij_Spasskij/ polnyj-mesjatseslov-vostoka-tom-ii-svjatoj-vostok/8, dostęp 29.03.2016 r.

Суперанская А. В., 1998, Словарь русских личных имен, Москва.

Тихонов А.Н., Бояринова Л.З., Рыжкова А.Г., 1995, Словарь русских личньх имен, Москва.

Требникъ, 1925, Варшава.

\section{BAPTISMAL NAMES OF ORTHODOX AND CATHOLICS OF BIELSK PODLASKI IN THE LATE $19^{\text {th }}$ AND EARLY $20^{\text {th }}$ CENTURIES}

\section{S U M M A R Y}

The paper presents baptismal names of inhabitants of Bielsk Podlaski from the years 1890-1909 excerpted from the church records of Orthodox parishes and a Roman Catholic parish. In the context of this confessional diversification the frequency of individual given names, their share in terms of the religious-cultural motivation and linguistic origin, as well as the forms in which they were recorded were analysed. 